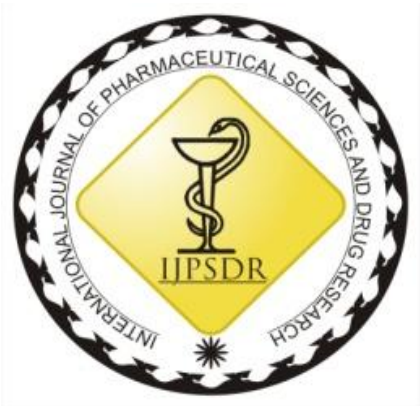

ISSN: 0975-248X

RESEARCH ARTICLE CODEN (USA): IJPSPP $($ (c) $)$ EY-NC-SA

\title{
A Validated Stability Indicating RP-HPLC Method Development For Anticancer Drug Enzalutamide in Bulk and Pharmaceuticals
}

\author{
B. Anjaneyulu Reddy ${ }^{1 *}$, P. Radhakrishnanand ${ }^{2}$, Md. Irshad Alam³ ${ }^{3}$ P. Ravi Kiran ${ }^{4}$ \\ ${ }^{1}$ Faculty of Science, Pacific Academy of Higher Education and Research University, Udaipur, Rajasthan, India \\ ${ }^{2}$ Daicel Chiral Technologies, Hyderabad, Telangana, India \\ ${ }^{3}$ Faculty of Science and Technology, Dr. Babasaheb Ambedkar Marathwada University, Aurangabad, \\ Maharashtra, India \\ ${ }^{4}$ Department of Chemistry, BITS-Pilani, Hyderabad Campus, Jawahar Nagar, Hyderabad, Medchal (Dist), \\ Telangana, India
}

Copyright (C) 2019 B. Anjaneyulu Reddy et al. This is an open access article distributed under the terms of the Creative Commons AttributionNonCommercial-ShareAlike 4.0 International License which allows others to remix, tweak, and build upon the work non-commercially, as long as the author is credited and the new creations are licensed under the identical terms.

\begin{abstract}
A reproducible stability-indicating Reverse Phase-HPLC technique for the quantification of Enzalutamide in in pharmaceuticals was developed and validated. Chromatography was done on Inertsil ODS- $\mathrm{C}_{18} 5 \mu \mathrm{m}(250 \mathrm{~mm} \times 4.6$ $\mathrm{mm}$ ) analytical column with acetonitrile: methanol: water in 40:30:30\% v/v proportion as a mobile phase and 1 $\mathrm{ml} / \mathrm{min}$ as a flow rate. Enzalutamide was detected at $237 \mathrm{~nm}$ UV-wavelength maximum. In the present work mobile phase used as diluents, developed technique was validated over $20-150 \mu \mathrm{g} / \mathrm{ml}$ linear concentration range for Enzalutamide. This method established with linearity coefficient value of 0.99 and the percentage recovery was found to be $99.3 \%$. This method was proven with LOD and LOQ findings of $0.53 \mu \mathrm{g} / \mathrm{ml}$ and $1.61 \mu \mathrm{g} / \mathrm{ml} \mathrm{respectively}$. The drug was degraded in acid and alkaline conditions and the percentage degradation values were $3.10 \%$ and 4.54 $\%$ respectively. There was no degradation of drug when exposed to neutral, UV, thermal, sun-light and oxidative conditions. Drug was undergoing degradation when exposed to acid and alkaline conditions. The developed technique was useful in the routine quantitation of Enzalutamide.
\end{abstract}

Keywords: Enzalutamide, Prostate cancer, RP-HPLC, Stability studies.

DOI: 10.25004/IJPSDR.2019.110303

Int. J. Pharm. Sci. Drug Res. 2019; 11(3): 85-90

*Corresponding author: Mr. B. Anjaneyulu Reddy

Address: Faculty of Science, Pacific Academy of Higher Education and Research University, Udaipur, Rajasthan, India

Tel.: +91-9652988065

E-mail $\bowtie$ : anjireddyss98@gmail.com

Relevant conflicts of interest/financial disclosures: The authors declare that the research was conducted in the absence of any commercial or financial relationships that could be construed as a potential conflict of interest.

Received: 14 February, 2019; Revised: 02 April, 2019; Accepted: 18 April, 2019; Published: 25 May, 2019

\section{INTRODUCTION}

Enzalutamide used in the treatment of prostate cancer, which inhibits the androgen receptor competitively and affects in different stages of signalling paths of cancer.
It inhibits the binding of androgen to androgenreceptor, nuclear translocation and consequent interface with DNA. This will results in decreasing the propagation of prostate cancer-cells, which finally leads 
to apoptosis and decrease in the tumour-volume. It was chemically designated as 4 -(3 - 4 - 4 -cyano-3(trifluoromethyl) phenyl) -5, 5- dimethyl -4-oxo-2thioxoimidazolidin-1-yl) -2-fluoro- $N$-methylbenzamide with molecular formula and weight of $\mathrm{C}_{21} \mathrm{H}_{16} \mathrm{~F}_{4} \mathrm{~N}_{4} \mathrm{O}_{2} \mathrm{~S}$ and $464.44 \mathrm{~g} / \mathrm{mol}$. [1-4] It is a selective antagonist of androgen receptor (AR) silently and biologically targets the androgens like DHT (dihydrotestosterone) and testosterone. As the first generation Non-selective androgen antagonists (NSAA) bicalutamide, it does not produce AR-translocation to the cell nucleus. In addition to this it inhibits the binding of AR to DNA (deoxyribonucleic acid) and AR-tocoactivator proteins. [5-6] So far, it has been mentioned as an AR-signaling preventer in addition to antagonism. This drug is designated as a "second-generation" NSAA, because it has significantly increased efficiency as an antiandrogen comparative to so called "first-generation" NSAAs like bicalutamide and flutamide. It has only 2 to 3 times lesser attraction for the AR comparative to $\mathrm{DHT}$ and the endogenous ligand of AR in prostate gland. [3]

When LNCaP-cells (a cell-line of prostate cancer) bring about to express higher levels of AR (as in the advanced prostate cancer) were cured with this drug, the androgen-dependent gene expression-PSA and TMPRSS was decreased in comparative to bicalutamide where the gene expression was increased. In VCaP-cells which over express the AR, the drug induced apoptosis whereas the bicalutamide drug won't. [78] Furthermore, it acts as W741C-mutant AR antagonist in comparative to bicalutamide, which acts as agonist when bind to the W741C-mutant. Literature survey of drug discloses that very few analytical procedures on LC-MS/MS, UV and RP-HPLC were reported for the analysis of pharmaceuticals. ${ }^{[9-12]}$ Hence the present research work is piercing to develop a sensitive, precise, economical, accurate and stability indicating technique for the quantification of Enzalutamide in API and dosage formulations.

\section{MATERIALS AND METHODS}

\section{Liquid chromatographic system}

Liquid chromatographic system (Shimadzu, Japan) consisted of a binary LC -20A CE pump, solvent degasifying system (DGU-20A), autosampler (SILHTC) and temperature controller (CTO-10 AS) for maintaining column temperature was used for the chromatographic elution of drug. Separation was achieved by optimized chromatographic conditions on Inertsil-ODS-C $18 \quad(250 \times 4.6 \mathrm{~mm}) 5 \mu \mathrm{m}$. All the chromatograms were processed and integrated using Empower-2 software.

\section{Chemicals and Reagents}

Enzalutamide pure drug obtained from Hetero drugs, Hyderabad, India. ACN and methanol of HPLC grade were procured form SD-Fine Chemicals, Mumbai, India. Other chemicals of analytical grade were bought from Qualigens chemicals, Mumbai, India.
Enzalutamide marketed formulations (Xtandi capsules) were obtained from local market for the sample analysis.<smiles>CNC(=O)c1ccc(N2C(=S)N(c3ccc(C#N)c(C(F)(F)F)c3)C(=O)C2(C)C)cc1F</smiles>

Fig. 1: Chemical structure of Enzalutamide

\section{Mobile Phase preparation}

It was processed by mixing HPLC-grade acetonitrile, methanol and water in 40:30:30\% $\mathrm{v} / \mathrm{v}$ proportion. The resultant mobile phase subjected for sonication for 10 to $15 \mathrm{~min}$ for degasification and filtered through 0.45 micron filter paper. In the present research work mobile phase were used as a diluent for sample and standard preparations.

\section{Protocol for Standard Solution}

Accurately weighed amount of $100 \mathrm{mg}$ of Enzalutamide working standard was transferred to a $100 \mathrm{ml}$ volumetric flask and drug was dissolved in few $\mathrm{ml}$ of mobile phase completely, then the final volume was make up to $100 \mathrm{ml}$ using mobile phase (diluent). Further dilutions were made with diluent to get $60 \mu \mathrm{g} / \mathrm{ml}$.

\section{Protocol for Sample Solution}

10 capsules were weighed separately and the mean of 10 capsules were calculated and recorded. An accurately weighed amount of Enzalutamide equivalent to $100 \mathrm{mg}$ was transferred and dissolved in $70 \mathrm{ml}$ of diluent by sonicating the solution for 30 minutes in a $100 \mathrm{ml}$ flask. Final volume was made up to the mark with diluent. The resulting solution was filtered and serial dilutions were processed to get $60 \mu \mathrm{g} / \mathrm{ml}$. The resultant solution filtered with the help of a $0.45 \mu$ membrane filter.

\section{Liquid Chromatography conditions}

Inertsil-ODS-C ${ }_{18}(250 \times 4.6 \mathrm{~mm}) 5 \mu \mathrm{m}$ fixed phase was used for the separation at $25^{\circ} \mathrm{C}$ as column oven temperature. The mobile phase was infused through the fixed phase at $1 \mathrm{ml} / \mathrm{min}$ flow rate. In the LC system the infusion volume was $10 \mu \mathrm{L}$. The photodiode array detection system was set to $\lambda$ max of $237 \mathrm{~nm}$ for the detection and chromatographic run time was 5 minutes.

\section{Validation}

The developed and optimized technique was validated in compliance with ICH validation parameters. [13-20]

\section{Precision}

Method precision was assessed by infusing the six solutions of standard into the HPLC system and \% RSD (relative standard deviation) was calculated.

\section{Specificity}

The method specificity was evaluated by comparing the drug solution with placebo solution by infusing 
into chromatographic system and the resulting chromatograms observed for the interference of drug response with placebo peak response. [15]

\section{Linearity}

Linearity of the analytical method was analyzed by processing series of replicates ranging from 20$150 \mu \mathrm{g} / \mathrm{ml}$ and infusing them into HPLC system.

\section{Accuracy}

Method accuracy was evaluated in the form of \% recovery. The drug solution along with sample was prepared in three variable concentrations of 50.0, 100.0 and 150.0 percentage. Then the percentage recovery was estimated. [13-14]

\section{Ruggedness}

Ruggedness was assessed by infusing the 6 standard solutions into chromatographic system for different days. The $\%$ RSD was calculated.

\section{Robustness}

Robustness of the method was assessed by fluctuating the optimized analytical conditions like mobile phase composition by $\pm 5 \%$, flow-rate by $\pm 0.1 \mathrm{ml} / \mathrm{min}$ and temperature of the oven by $\pm 5^{\circ} \mathrm{C}$. ${ }^{[17-18]}$

\section{Solution stability}

Stability of solution was assessed by analyzing the standard drug solution after storage for $24 \mathrm{~h}$ at laboratory conditions.

\section{Ruggedness}

Ruggedness was evaluated by infusing the 6 solutions of standard into HPLC for different days. The \% RSD was calculated. [20]

\section{Forced degradation studies}

Forced degradation studies were processed with acid, oxidative, alkaline, photolytic, thermal, and ultra violet (UV) degradations on sample. The drug sample was processed by exposing to these stress environments and the peak purity was determined from the resulting chromatograms, which indicates that the technique was effectively separated the degrade components from the standard. [19]

\section{Acid degradation}

It was processed by utilizing $0.1 \mathrm{M}$ Hydrochloric acid solution. $10 \mathrm{mg}$ of Enzalutamide pure drug was transferred in to a $10 \mathrm{ml}$ volumetric flask. Drug was made solubilize in $5 \mathrm{ml}$ of $0.1 \mathrm{M}$ Hydrochloric acid and solution was exposed to $80^{\circ} \mathrm{C}$ temperature in a hot water bath. Samples were processed at different timings such as $0.0 \mathrm{~min}, 30.0 \mathrm{~min}, 1.0 \mathrm{~h}, 2.0 \mathrm{~h}$, and $4.0 \mathrm{~h}$. At variable time intervals, samples were collected and $5.0 \mathrm{ml}$ of methanol was added vortexed for $5 \mathrm{~min}$. From the resulting solution serial dilutions were processed get $60 \mu \mathrm{g} / \mathrm{ml}$ with diluent. Finally the resulting solution was filtered through 0.22 micrometer filter paper and infused in to LC-system.

\section{Alkali degradation}

It was processed by utilizing $0.1 \mathrm{M}$ sodium hydroxide solution. $10 \mathrm{mg}$ of Enzalutamide pure drug was transferred in to a $10.0 \mathrm{ml}$ volumetric flask. Drug was made solubilize in $5.0 \mathrm{ml}$ of $0.01 \mathrm{M}$ sodium hydroxide, and solution was exposed to $80^{\circ} \mathrm{C}$ temperature in a hot water bath. Samples were processed at different timings such as $0.0 \mathrm{~min}, 30.0 \mathrm{~min}, 1.0 \mathrm{~h}, 2.0 \mathrm{~h}$, and $4.0 \mathrm{~h}$. At variable time intervals, samples were collected and $5.0 \mathrm{ml}$ of methanol was added vortexed for $5 \mathrm{~min}$. From the resulting solution serial dilutions were processed get $60 \mu \mathrm{g} / \mathrm{ml}$ with diluent. Finally the resulting solution was filtered through 0.22 micrometer filter paper and infused in to LC-system.

\section{Oxidative degradation}

For oxidation, hydrogen peroxide (3\%) selected as reagent. $10 \mathrm{mg}$ of the standard drug was transferred in to a $10.0 \mathrm{ml}$ volumetric flask. Drug was made solubilize in $5.0 \mathrm{ml}$ of $\mathrm{H}_{2} \mathrm{O}_{2}$. Resulting solution was kept a side for room temperature. Samples were processed at different timings as mentioned in acid degradation study and prepare $60 \mu \mathrm{g} / \mathrm{ml}$ by serial dilution and infused into LC-system.

\section{Neutral degradation}

It was processed by utilizing distilled water. $10 \mathrm{mg}$ of the standard drug was transferred in to a $10.0 \mathrm{ml}$ volumetric flask. Drug was made solubilize in $5.0 \mathrm{ml}$ of distilled water, and solution was exposed to $80^{\circ} \mathrm{C}$ temperature in a hot water bath. Then the flask was heated on a water-bath to attain $80^{\circ} \mathrm{C}$. Samples were processed at different timings as mentioned in acid degradation study and prepare $60 \mu \mathrm{g} / \mathrm{ml}$ by serial dilution and infused into LC-system.

\section{Thermal degradation}

It was processed by placing the standard drug at $40^{\circ} \mathrm{C}$ in an incubator. Samples were collected at definite time intervals. The weighed amount of sample was added to $5 \mathrm{ml}$ of HPLC-grade methanol and vortexed for $5 \mathrm{~min}$. Final volume was made to get $1000 \mu \mathrm{g} / \mathrm{ml}$. From that serial dilutions were made to get $60 \mu \mathrm{g} / \mathrm{ml}$ with diluent. It was vortexed and filtered with a $0.22 \mu \mathrm{m}$ filter, and $20 \mu \mathrm{L}$ of sample was infused into LC-system.

\section{UV-degradation}

$100 \mathrm{mg}$ of pure drug was weighed and transferred to a clean petri-dish. Then the petri-dish was positioned under a UV chamber by maintaining $30 \mathrm{~cm}$ distance. The petri-dish cover was removed for degradation. After $3 \mathrm{~h}$, the UV-lamp was switched to off and $10 \mathrm{mg}$ drug sample was taken and $1000 \mu \mathrm{g} / \mathrm{ml}$ was processed with diluent, from which $60 \mu \mathrm{g} / \mathrm{ml}$ concentration was processed by serial dilution. It was vortexed and filtered through a $0.22 \mu \mathrm{m}$ filter. Twenty microlitres of the sample was infused into LC-system.

\section{Photolytic degradation}

For photolysis condition, $100 \mathrm{mg}$ of the pure drug was weighed and transferred to a clean petri-dish and closed. Then the petri-dish was exposed to direct sunlight. At different timings, $10 \mathrm{mg}$ of drug sample was taken out. From it, a stock solution of $1000 \mu \mathrm{g} / \mathrm{ml}$ was processed with diluent, and $60 \mu \mathrm{g} / \mathrm{ml}$ concentration was processed by serial dilution. It was vortexed and filtered through a $0.22 \mu \mathrm{m}$ filter. Twenty micro liters of the sample was infused into LC-system. $[13,19]$ 
B. Anjaneyulu Reddy et al. / A Validated Stability Indicating RP-HPLC Method Development For Anticanc
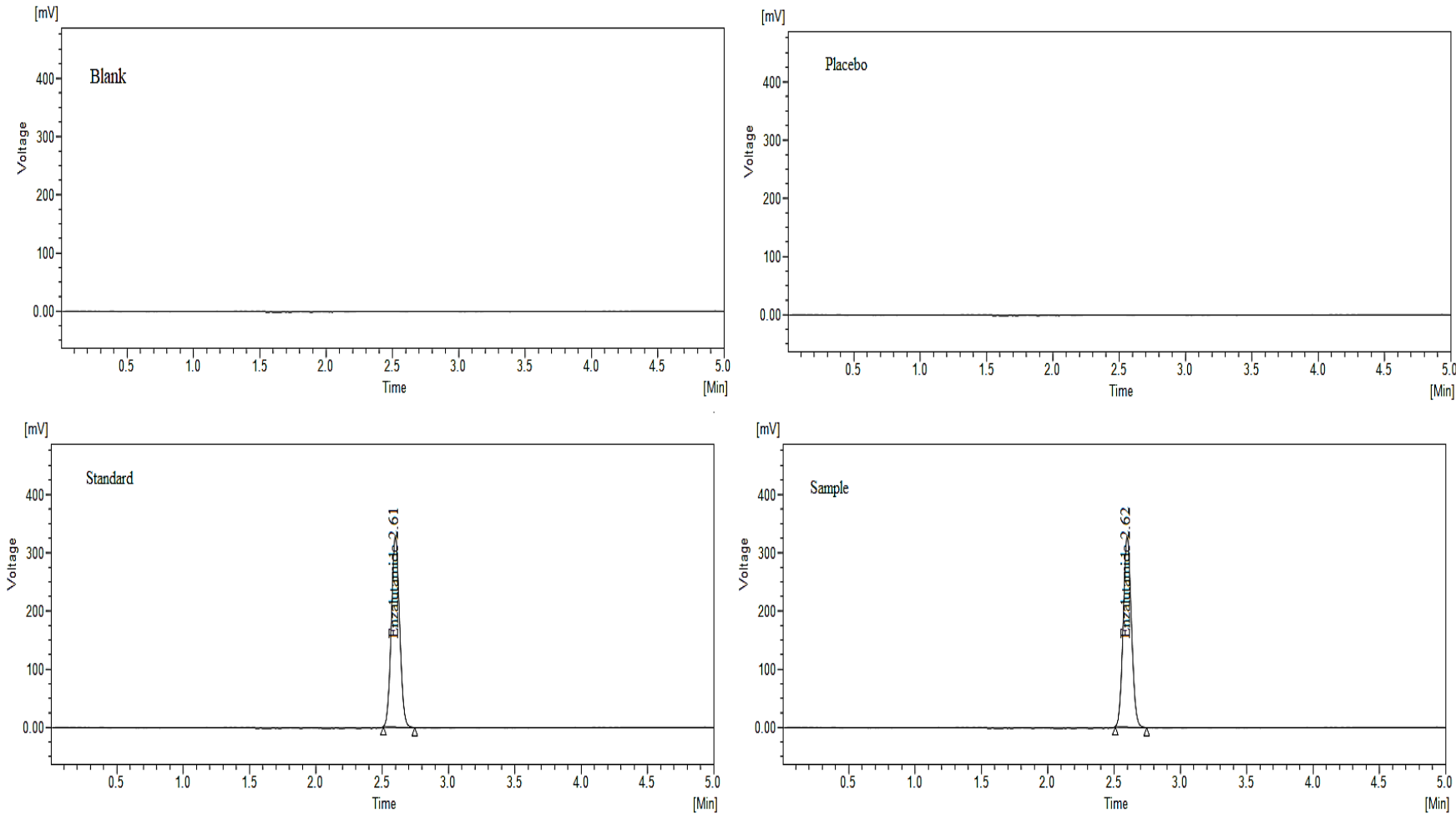

Fig. 2: Chromatograms of Enzalutamide Blank, Placebo, Standard and Sample
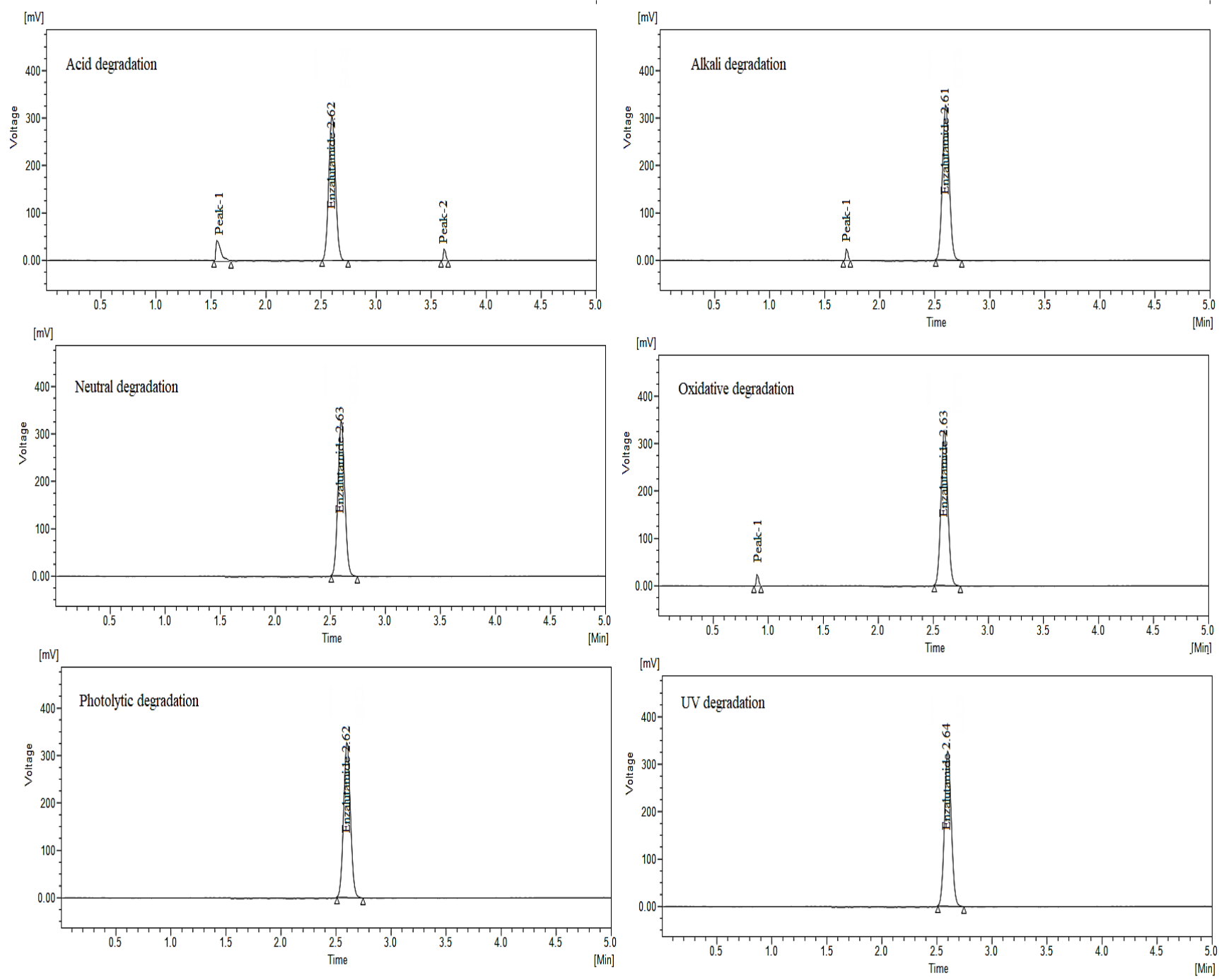

Fig. 3: Chromatograms of enzalutamide forced degradation studies 
Table 1: Validation results for Enzalutamide

\begin{tabular}{|c|c|c|}
\hline Parameter & Result (mean \pm SD) & \\
\hline Precision (\%RSD, n) & $0.96(100.08 \pm 0.96)$ & \\
\hline Specificity & No interference & \\
\hline Accuracy (\% Recovery, n mean \pm SD) & $99.58 \% \pm 0.28-99.89 \% \pm 0.19$ & \\
\hline Linearity & $20-150 \mu \mathrm{g} / \mathrm{ml}$ & \\
\hline Correlation coefficient $\left(\mathrm{r}^{2}\right)$ & 0.9998 & \\
\hline LOD concentration & $0.18 \mu \mathrm{g} / \mathrm{ml}$ & \\
\hline LOQ concentration & $0.58 \mu \mathrm{g} / \mathrm{ml}$ & \\
\hline \multirow[t]{2}{*}{ Ruggedness(\%RSD, n) } & Day 1 & Day 2 \\
\hline & 0.92 & 0.82 \\
\hline Robustness (\%RSD, n) & Decrease in flow rate 0.8 & Increased flow rate 0.18 \\
\hline \multirow[t]{2}{*}{ (Organic phase) } & Decrease in mobile phase 0.4 & Increased mobile phase (Organic) 0.65 \\
\hline & Decreased column temperature 0.5 & Increased column temperature 1.02 \\
\hline Solution stability & Day $1(0 \mathrm{~h})$ & Day 2 (After $24 \mathrm{~h})$ \\
\hline$(\%$ RSD, $\mathrm{n})$ & 0.85 & 1.25 \\
\hline$(\%$ Assay, $n)$ & $100.12 \pm 0.97$ & $99.85 \pm 1.05$ \\
\hline USP-tailing & 1.36 & \\
\hline USP theoretical plates & 3789 & \\
\hline
\end{tabular}

n-number of samples, i.e., six samples for estimation; SD- Standard deviation

Table 2: Forced degradation results for Enzalutamide

\begin{tabular}{cccc}
\hline Stress condition & \% Assay & $\begin{array}{c}\text { \% area of } \\
\text { degradation peak }\end{array}$ & \% Degradation \\
\hline $\begin{array}{c}0.1 \mathrm{M} \mathrm{HCl} \text { for } 4 \mathrm{~h} \text { at } \\
80^{\circ} \mathrm{C}\end{array}$ & 96.90 & 2.65 & 3.10 \\
$0.1 \mathrm{M} \mathrm{NaOH}$ for $4 \mathrm{~h}$ at & 95.46 & - & 4.54 \\
$80^{\circ} \mathrm{C}$ & 96.20 & - & 3.80 \\
$3 \% \mathrm{H}_{2} \mathrm{O}_{2}$ for $4 \mathrm{~h}$ & 99.50 & - & 0.50 \\
Water for $4 \mathrm{~h}$ at $80^{\circ} \mathrm{C}$ & - & 1.88 \\
$\mathrm{UV}$ light for $3 \mathrm{~h}$ & 98.12 & - & 1.66 \\
\hline Thermal) $40^{\circ} \mathrm{C}$ for $6 \mathrm{~h}$ & 98.34 & &
\end{tabular}

\section{RESULTS}

\section{Method development}

Method was optimized after trials with different types of columns, mobile phase composition and flow rate. The optimized method was processed with InertsilODS-C $18(250 \mathrm{~mm} \times 4.6 \mathrm{~mm}) 5 \mu \mathrm{m}$ analytical column with acetonitrile: methanol: water in the proportion of 40:30:30\% v/v as mobile phase at $1 \mathrm{ml} / \mathrm{min}$ flow rate. Drug was detected at $237 \mathrm{~nm}$ UV-wavelength maximum. The chromatograms for the optimized method were shown in the Fig. 2.

\section{Validation}

The optimized technique was validated in compliance with $\mathrm{ICH}$ validation parameters and the results were shown in Table 1.

\section{Forced degradation studies}

Forced degradation studies [13] were processed for the enzalutamide drug by exposing the drug solution to different stress environments such as acidic $(0.1 \mathrm{~N}$ hydrochloric acid for $4 \mathrm{~h}$ at $\left.80^{\circ} \mathrm{C}\right)$, basic $(0.1 \mathrm{~N}$ sodium hydroxide for $4 \mathrm{~h}$ at $\left.80^{\circ} \mathrm{C}\right)$, peroxide $(3 \%$ hydrogen peroxide for $4 \mathrm{~h}$ at $60^{\circ} \mathrm{C}$ ), neutral (refluxing the drug in water for $4 \mathrm{~h}$ at $80^{\circ} \mathrm{C}$ ), photolytic (UV-light for $3 \mathrm{~h}$ ) and thermal $\left(40^{\circ} \mathrm{C}\right.$ for $\left.6 \mathrm{~h}\right)$ conditions. All the findings of forced degradation findings were presented in Table 2 and respective chromatograms were shown in Fig. 3.

\section{DISCUSSION}

In the present specific RPHPLC-technique, linearity was assessed over the concentration level of 20$150 \mu \mathrm{g} / \mathrm{ml}$, the research work was successfully validated, and the validation constraints were within the acceptable limits (Table 1 and Fig. 2). In this liquid chromatographic technique, the LOD and LOQ of drug were $0.18 \mu \mathrm{g} / \mathrm{ml}$ and $0.58 \mu \mathrm{g} / \mathrm{ml}$, respectively. In present technique, Enzalutamide was exposed to its stress studies under different environments as per the ICH-guidelines. The neutral/hydrolytic degradation study of Enzalutamide reveals that no degradants were observed for $4.0 \mathrm{~h}$ in neutral environment. The findings of acid hydrolysis shown that degradation component peaks at $1.59 \mathrm{~min}$ and $3.63 \mathrm{~min}$ along with drug peak. From the chromatogram it was observed that $3.10 \%$ of drug was degraded in $0.1 \mathrm{M}$ hydrochloric acid at $80^{\circ} \mathrm{C}$.

Enzalutamide was degraded in $0.01 \mathrm{M}$ sodium hydroxide at $80.0^{\circ} \mathrm{C}$ for $4.0 \mathrm{~h}$, and the degradation peak was eluted at $1.72 \mathrm{~min}$ in the chromatogram. From the chromatogram the drug percentage degradation was $4.54 \%$. Enzalutamide did not degrade after it was kept under direct sunlight for 21 days. Drug under UVchamber for $48.0 \mathrm{~h}$ it was not underwent degradation, observed from the resulting chromatogram. The chromatogram of oxidative degradation of drug was showed that no degradants were formed after $4 \mathrm{~h}$ of exposure. The chromatogram of thermal degradation showed that enzalutamide was not degraded for 15 days at $40^{\circ} \mathrm{C}$.

In this research article Stability-indicating Reverse Phase-HPLC technique for Enzalutamide was developed and validated. All the validation parameters: selectivity, accuracy, precision, recovery, robustness, and ruggedness were within the acceptance limit. The drug sample was resolved on Inertsil-ODS$\mathrm{C}_{18}(250 \mathrm{~mm} \times 4.6 \mathrm{~mm}) 5 \mu$ manalytical column with acetonitrile: methanol: water in the proportion of $40: 30: 30 \% \mathrm{v} / \mathrm{v}$ as mobile phase at $1 \mathrm{ml} / \mathrm{min}$ flow rate. Enzalutamide was detected at $237 \mathrm{~nm}$ UV-wavelength maximum.The drug was degraded in acid and alkaline conditions and the percentage degradation values were $3.10 \%$ and $4.54 \%$ respectively. There was no degradation of drug when exposed to neutral, UV, thermal, sun-light and oxidative conditions. The drug was successfully estimated by this technique and it was 
useful for laboratories for the routine analysis of Enzalutamide in bulk and pharmaceuticals.

\section{REFERENCES}

1. Gibbons JA, Ouatas T, Krauwinkel W, Ohtsu Y, van der Walt JS, Beddo V, de Vries M, Mordenti J. Clinical pharmacokinetic studies of enzalutamide. Clin Pharmacokinet. 2015;54(10):1043-55.

2. Kim TH, Jeong JW, Song JH, Lee KR, Ahn S, Ahn SH, Kim S, Koo TS.Pharmacokinetics of enzalutamide, an anti-prostate cancer drug, in rats. Archives of Pharmacal Research 2015;38 (11): 2076-82.

3. Benoist GE, Hendriks RJ, Mulders PF, Gerritsen WR, Somford DM, Schalken JA, van Oort IM, Burger DM, van Erp NP. Pharmacokinetic aspects of the two novel oral drugs used for metastatic castration-resistant prostate cancer: Abiraterone acetate and enzalutamide. ClinPharmacokinet. 2016; 55 (11):1369-1380.

4. Saad F, Heinrich D. New Therapeutic Options for Castrationresistant Prostate Cancer. The Journal of Oncopathology. 2013; 1 (4): 23-32.

5. Scher HI, Fizazi K, Saad F, et. al. Increased survival with enzalutamide in prostate cancer after chemotherapy. The New England Journal of Medicine. 2012;367 (13):1187-97.

6. Antonarakis ES. Enzalutamide: the emperor of all antiandrogens. Translational Andrology and Urology. 2013; 2 (2): 119-120.

7. Payton S. Prostate cancer: enzalutamide impresses in European studies. Nature Reviews. Urology. 2014; 11(5): 243.

8. Tombal B, Borre M, et. al. Long-term Efficacy and Safety of EnzalutamideMonotherapy in Hormone-naïve Prostate Cancer: 1- and 2-Year Open-label Follow-up Results. European Urology. 2015; 68(5): 787-94.

9. Saini NK, Sulochana SP. Development and validation of a novel method for simultaneous quantification of enzalutamide, darolutamide and their active metabolites in mice dried blood spots using LC-MS/MS: application to pharmacokinetic study in mice. ADMET \& DMPK. 2018; 6(3):242-257.

10. Prajapati DJ, Usmangani K. Quantification of newer anticancer drug enzalutamide by RP-LC method and UV- visible spectroscopic method in bulk and synthetic mixture.J MolOncolRes. 2017; 1(2):65-73.

11. Benoist M, van der Meulen E, Oort IV, Schalken J, Gerritsen W, BurgerNielka P van Erp D. Development and validation of a bioanalytical assay on LC/MS/MS to quantify enzalutamide and $\mathrm{N}$-desmethylenzalutamide in human plasma. Journal of clinical oncology. 2016; 34:330.

12. Puszkiel A, Ple A, Huillard O, Noe G. A simple HPLC-UV method for quantification of enzalutamide and its active metabolite N-desmethylenzalutamide in patients with metastatic castration-resistant prostate cancer. J Chromatogr B AnalytTEchnol Biomed Life Sci. 2017; 15(1058):102-107.

13. Patil N, Ommurugan B, Udupa KS, Rao K. Bortezomib induced subconjunctival hemorrhage. Asian J Pharm Clin Res. 2017; 10:10-1.

14. Charde MS, Welankiwar AS, Chakole RD. Development of validated RP-HPLC method for the simultaneous estimation of atenolol and chlorthalidone in combine tablet dosage form. International Journal of Advances in Pharmaceutics. 2014; 3 (1):1-11. 6-18.

15. Estella Hermoso de Mendoza A, Imbuluzqueta I, et al. Development and validation of ultra-high performance liquid chromatography-mass spectrometry method for LBH589 in mouse plasma and tissues. J Chromatogr B: Anal Technol Biomed Life Sci. 2011; 879:3490-6.

16. Madhavi S, Prameela Rani A. Simultaneous reverse phase ultra-performance liquid chromatography method development and validation for estimation of Grazoprevir and Elbasvir. Asian J Pharm Clin Res. 2018; 11:100.

17. ICH: Q2 (R1), Validation of analytical procedures: text and methodology; 2005.

18. ICH: Q2B. Harmonized Tripartite Guideline, Validation of Analytical Procedure: Methodology, IFPMA, in: Proceedings of the International Conference on Harmonization, Geneva; 1996.

19. Ngwa G. Forced degradation studies as an integral part of HPLC stability indicating method development. Drug Delivery Technol. 2010; 10:56-9.

20. Mule KL. Rapid analytical method for assay determination for prochlorperazine edisylate drug substances by Ultra performance liquid chromatography. Int J Curr Pharm Res. 2017; 9:118-22.

HOW TO CITE THIS ARTICLE: Anjaneyulu Reddy B, Radhakrishnanand P, Irshad Alam M, Ravi Kiran P. A Validated Stability Indicating RP-HPLC Method Development For Anticancer Drug Enzalutamide in Bulk and Pharmaceuticals. Int. J. Pharm. Sci. Drug Res. 2019; 11(3): 85-90. DOI: 10.25004/IJPSDR.2019.110303 